\title{
DROUGHT-TOLERANT MAIZE GENOTYPES INVEST IN ROOT SYSTEM AND MAINTAIN HIGH HARVEST INDEX DURING WATER STRESS
}

\author{
RONIEL GERALDO AVILA ${ }^{1}$, PAULO CÉSAR MAGALHÃES ${ }^{2}$, AMAURI ALVES DE ALVARENGA ${ }^{1}$, \\ ALYNE DE OLIVEIRA LAVINSKY², CLEIDE NASCIMENTO CAMPOS ${ }^{3}$, \\ THIAGO CORRÊA DE SOUZA ${ }^{4}$ and CARLOS CÉSAR GOMES JÚNIOR ${ }^{4}$
}

\author{
${ }^{1}$ Universidade Federal de Lavras, Minas Gerais, Brasil-ronielgeraldo@yahoo.com.br (corresponding author), \\ amauriaa@dbi.ufla.com.br \\ ${ }^{2}$ Embrapa Milho e Sorgo, Sete Lagoas, Minas Gerais, Brasil-paulo.magalhaes@embrapa.br,alynelavinsky@gmail.com \\ ${ }^{3}$ Universidade Estadual de Campinas, Campinas, São Paulo,Brasil-cleiidecampos@hotmail.com \\ ${ }^{4}$ Universidade Federal de Alfenas, Alfenas, Minas Gerais, Brasil-thiagonepre@hotmail.com, juninhoiam@yahoo.com.br
}

Revista Brasileira de Milho e Sorgo, v.15, n.3, p. 450-460, 2016

\begin{abstract}
Drought is considered the primary limitation to agriculture and, can reduce grain yield by up to $60 \%$ when occurs at pre-flowering in maize. In this context this research, aimed to understand the maize genotypes behavior to drought management and carbon partitioning between grain production and structures to maintain hydration when submitted to drought. Maize genotypes tolerant (DKB390 and P30F35) and sensitive (BRS1010 and 2B710) to drought were grown in a greenhouse using two water conditions: irrigated and stressed. Water deficit was imposed at pre-flowering and maintained for twelve days. Leaf water potential, gaseous exchange and male and female flowering interval were evaluated. At the end of the cycle, production components and root/shoot ratio dry weight were evaluated. Drought-tolerant genotypes used root system as a mechanism of tolerance to drought, which ensure greater efficiency in absorption and loss of water and, consequently, greater stomatal conductance during the drought, compared to the sensitive-genotypes. In addition, drought-tolerant genotypes showed greater stability in the source-sink relationship, exhibiting higher photosynthetic rate and harvest index.
\end{abstract}

Keywords: water stress, carbon partitioning; root/shoot ratio dry weight, gas exchanges, Zea mays.

\section{GENÓTIPOS DE MILHO TOLERANTES À SECA INVESTEM EM SISTEMA RADICULAR E MANTEM ALTO ÍNDICE DE COLHEITA DURANTE O ESTRESSE HÍDRICO}

RESUMO- A seca é considerada restrição primária à agricultura, e no milho, quando ocorre no pré-florescimento, pode reduzir o rendimento de grãos em até $60 \%$. Neste contexto, objetivou-se entender como genótipos de milho contrastantes para tolerância à seca, gerenciam o particionamento de carbono entre produção de grãos e estruturas de manutenção da hidratação durante a seca. Para isso, em casa de vegetação cultivaram-se genótipos de milho tolerantes (DKB390 e P30F35) e sensíveis (BRS1010 e 2B710) à seca, em duas condições hídricas: irrigado normal e déficit hídrico. No pré-florecimento foi imposto o déficit hídrico, que foi mantido por doze dias. Posteriormente avaliou-se o potencial hídrico foliar, trocas gasosas e intervalo de florescimento masculino e feminino. No final do ciclo, avaliaram-se os componentes de produção e a razão raiz/parte aérea. Constatou-se que, genótipos tolerantes utilizaram preferencialmente sistema radicular como um mecanismo de tolerância à seca, o que garantiu a esses genótipos, maior eficiência entre a absorção e perda de água e, consequentemente, maior condutância estomática durante a seca, em relação aos genótipos sensíveis. Além disso, os genótipos tolerantes apresentaram maior equilíbrio em suas relações fonte e dreno, exibindo maiores taxa fotossintética e índice de colheita.

Palavras-chave: estresse hídrico, particionamento de carbono, razão raiz/parte aérea, trocas gasosas, Zea mays. 
World's human population is projected to reach approximately 9.6 billion of people in 2050 (Lee et al., 2011). It is believed that these people will be more urban and will have a greater purchasing power. Moreover, these people will become more rigorous in your diet, increasing mainly the consumption of cereals. In this way, it is estimated that grain production will have to overcome the current 2.1 billion tons to 3 billion tons (FAO, 2015). This has generated major concerns in world food security, since the increase in crop yield per area has been reduced in the last decade. Besides that, the world is undergoing climate change, which has generated changes in precipitation patterns and causing long periods of drought. Drought is considered the primary limitation on agriculture and causes significant impacts around the world, putting at risk food production and consequently food security of population (Lobell \& Gourdji, 2012).

Losses in crop production caused by drought is affected by duration and intensity of stress, phenological stage and genetic material. Maize plants subjected to water stress during pre-flowering reduced grain yield in 60\% (Magalhães \& Durães, 2008). This reduction can be due to a decrease in stomatal conductance and photosynthesis. Restriction in energy supply for development of reproductive organs anticipates physiological maturity of tassel in up to eight days in relation to ear, making fertilization impossible (Setter \& Flannigan, 2001). After fertilization, low availability of hexoses for the developing grains may lead to grain abortion, and cause the production of ear with fewer rows and rows with reduced grains number, and empty grains (Bergamaschi et al., 2004; Magalhães \& Durães, 2008).

Therefore, the development of cultivars with drought adaptations and high yields has been the focus of many plant breeding programs. In this scenario, roots play a fundamental role, since this organ is responsible for water acquisition, and is an important component of plant adaptation to waterlimited environments (Lynch et al., 2014). According to Lavinsky et al. (2015b), maize genotypes that invest carbon in roots during drought conditions are more productive, since improve water absorption and maintain higher values of stomatal and mesophyll conductance. Furthermore, genotypes that invest carbon in roots maintain higher photosynthetic rates in relation to those genotypes that invest in shoots.

In addition to this strategy, Yang et al. (2001) observed that when photosynthesis is insufficient to maintain the development of grains, carbon is partitioned from reserves to grains, keeping the normal development of these organs. In this context, the present study aimed to understand how maize genotypes contrasting for drought tolerance manage the carbon partitioning between grain production and structures to maintain hydration when submitted to drought.

\section{Material and Methods}

\section{Growing conditions, plant material and experimental design}

The experiment was conducted under greenhouse conditions at National Maize and Sorghum Research Center (EMBRAPA), in Sete Lagoas, State of Minas Gerais, Brazil (altitude of $732 \mathrm{~m}, 1^{\circ} 28^{\prime}$ S, 4415'08" W). Plant material consisted of four contrasting maize hybrids for drought tolerance, two tolerant (DKB390 and P30F35) and two sensitive (BRS1010 and 2B710). Experimental design was completely randomized in a $2 \times 4$ factorial scheme, with two water conditions and four genotypes, with four replications. 
Plants were cultivated in $20 \mathrm{~L}$ plastic pots containing a typical Dystrophic Red Latosol. Water content in the soil was daily monitored, in the morning and afternoon (9 a.m. and 3 p.m.) using soil moisture sensors GB Reader N1535 (Measurement Engineering, Australia), buried in the center of pots, at the depth of $20 \mathrm{~cm}$. These sensors detect water tension in the soil based on electric resistance and were attached to digital measurement devices. Water replenishment was performed based on the readings obtained with the sensor and the water was replenished, until field capacity during the period that preceded the treatment establishment. Water replacement calculations were performed using a spreadsheet, made according to water retention curve of the soil. In parallel, cultivation and phytosanitary treatments were carried out, according to the maize crop demand. The experimental unit consisted of a pot containing two plants, with four replications per treatment.

At the pre-flowering stage, half of the treatments was submitted to water deficit (WD) and the other half continued to receive irrigation daily in order to maintain soil moisture near to field capacity (FC), with water tension in the soil approximately -18 $\mathrm{kPa}$. Induction of water stress was daily performed by applying at least $50 \%$ of the total water available, i.e., until water tension in the soil reached at least $-138 \mathrm{kPa}$, a value which corresponded to the specified soil. This stress was maintained for 20 days. After this period, the stress was suspended, and the plants were normally irrigated until the end of the cycle.

\section{Biophysical analysis}

After twelve days of stress, leaf gaseous exchanges were evaluated between 9 a.m. and 10 a.m. in the leaf where occurs ear insertion, using an infrared gas analyzer (IRGA), model LI 6400 (LI-COR, Lincoln, NE, USA), equipped with a fluorometer (LI-6400-40, LI-COR Inc.). Leaf water potential was measured using a Scholander pressure pump at midday ( $\Psi \mathrm{md})$.

\section{Agronomic parameters}

At the end of the cycle, plants were divided into root, stems, leaves, tassel, ear (cob, straw and grains) and dried at $70^{\circ} \mathrm{C}$ for $72 \mathrm{~h}$. Subsequently, using a digital analytical balance, the total dry weight of plants was measured. Root/shoot ratio dry weight and crop index were assessed (Durães et al., 2002). Analyzes of ear were performed by direct counting, evaluating number of row and number of grains per row. Ear diameter was evaluated using a pachymeter and ear length was measured using a graduated ruler. Preliminary statistical tests were applied to fit or not the results to analysis of variance (ANOVA). ScottKnott test at $5 \%$ probability was used in order to test the contrast between treatments.

\section{Results}

To verify the ability of contrasting genotypes in maintaining their leaf water status under water deficit, leaf water potential at midday ( $\Psi \mathrm{md}$ ) was analyzed (Figure 1). Genotypes under water restriction (soil water tension of $-138 \mathrm{kPa}$ ) showed lower leaf water potential than those submitted to field capacity (soil water tension of $-18 \mathrm{kpa})$. In addition, under water deficit the drought-tolerant genotypes (DKB390 and P30F35) showed greater leaf water potential than drought-sensitive genotypes (BRS1010 and 2B710). This suggests that tolerant genotypes have 
mechanisms that contribute to the maintenance of Imd under drought conditions.

Regarding male and female flowering intervals, it was observed that only drought-tolerant genotype DKB390 did not show significant increases in this parameter when submitted to water deficit during preflowering (Figure 2). Under water deficit, BRS1010, a sensitive genotype, increased from 0.5 to 6 days the difference between tassel and ear emission and thus reached a difference considered harmful for fertilization and for grain yield.

Means followed by the same letter do not differ statistically. Lowercase letters denote comparisons between genotypes within the same soil water level and uppercase letters indicate comparisons between soil water levels within the same genotype. The Scott-Knotttestat at 5\% probability was applied.

Development of reproductive organs is a process that requires high levels of energy. Thus, changes in gaseous exchange patterns governed by drought can have direct effects in grain development (Figure 3). A reduction in gaseous exchange parameter was observed in all genotypes submitted to water deficit, compared to those maintained at field capacity. However, drought-tolerant genotypes under water deficit showed higher photosynthesis (Figure 3A), stomatal conductance (Figure 3B) and transpiration (Figure 3C) than sensitive genotypes (2B710 and BRS1010).

It was also evaluated the ability of genotypes to manage water loss due to carbon assimilation (Figure 3D). DKB390, P30F35 and 2B710 genotypes, when submitted to water deficit, increased water use efficiency (A/E) compared to those maintained at field capacity. In addition, BRS1010 when submitted to water deficit maintained the same $\mathrm{A} / \mathrm{E}$ of plants in field capacity and showed the lowest values compared to the other genotypes under drought.

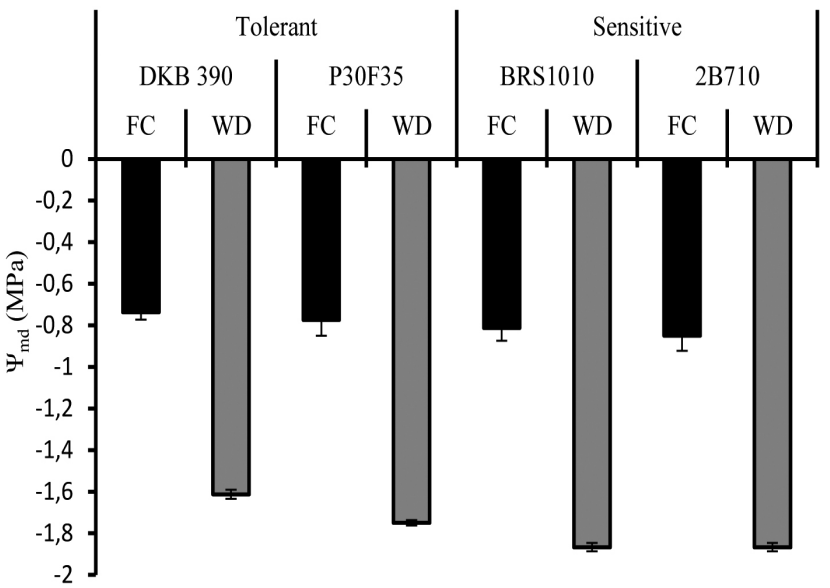

Figure 1. Leaf water potential at midday ( $\Psi \mathrm{md})$ in four maize genotypes with contrasting characteristics for drought tolerance submitted to different water levels in the soil during pre-flowering. Bars represent the standard error of the means of four replications.

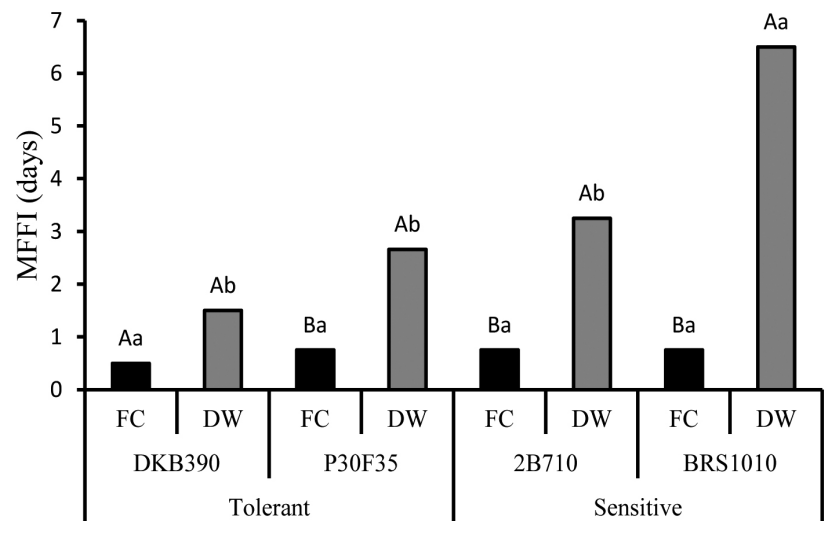

Figure 2. Male and female flowering intervals in four maize genotypes with contrasting characteristics for drought tolerance submitted to different water levels in the soil during pre-flowering.

Drought, in general, altered productivity components despite the genotype analyzed (Table 1). However, drought-tolerant genotypes (DKD390 and P30F35) did not reduced ear length (EL) due to drought. In contrast, drought-sensitive genotypes showed lower ear length when compared to sensitive genotypes in field capacity and drought-tolerant 

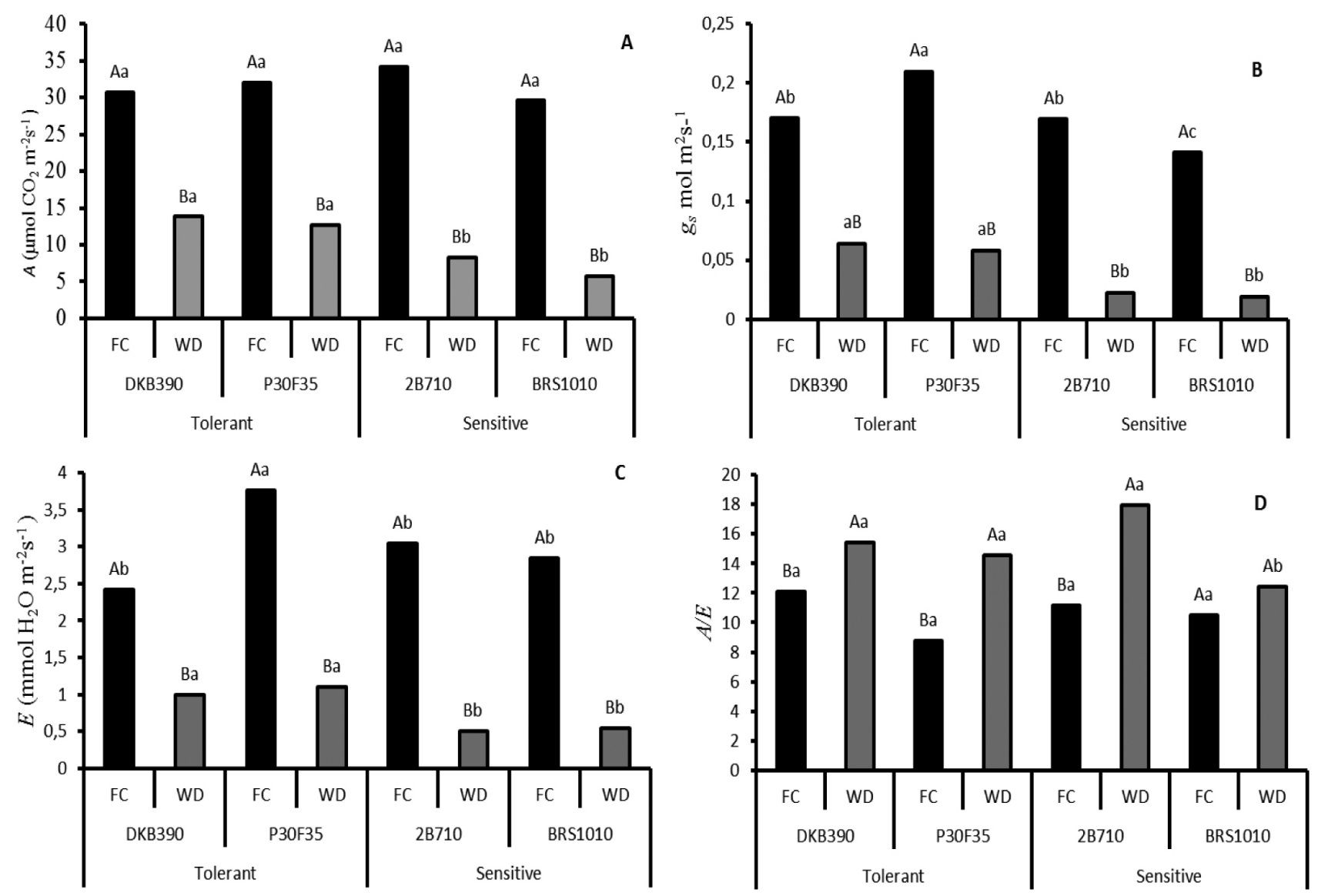

Figure 3. Gaseous exchange parameters in four maize genotypes with contrasting characteristics for drought tolerance submitted to different water levels in the soil during pre-flowering.

A- $A$ : photosynthetic rate $\left(\mu \mathrm{mol} \mathrm{CO}_{2} \mathrm{~m}^{-2} \mathrm{~s}^{-1}\right)$; $\mathrm{B}-g s$ : stomatal conductance $\left(\mathrm{mol} \mathrm{H}_{2} \mathrm{O} \mathrm{m}^{-2} \mathrm{~s}^{-1}\right)$; $\mathrm{C}$ - E: transpiration rate $\left(\mathrm{mmol} \mathrm{H}_{2} \mathrm{O} \mathrm{m}^{-2} \mathrm{~s}^{-1}\right)$; and $\mathrm{D}-A / E$ : water use efficiency..

Means followed by the same letter do not differ statistically. Lowercase letters denote comparisons between genotypes within the same soil water level and uppercase letters indicate comparisons between soil water levels within the same genotype. The Scott-Knott test at 5\% probability was applied.

genotypes under water deficit. Among the droughtsensitive genotypes, BRS1010 showed the lowest ear length, with reduction of $43 \%$ when compared to plants of this same genotype in field capacity.

It was also observed that ear diameter was more strongly affected by drought than ear length (Table 1). Also, all analyzed genotypes showed reduced ear diameter (ED) under drought conditions in relation to those at field capacity. In addition, under drought conditions, F30F35 showed the highest ear diameter, followed by DKB390 and 2B710. The lowest values of ear diameter were obtained in BSR1010. Among the genotypes maintained at field capacity the highest ear diameter was observed in P30F35 and 2B710.

At field capacity, 2B710 showed the highest number of rows per ear (NRE) and BRS1010 the lowest (Table 1). In addition, no differences were observed in drought-tolerant genotypes under 
Table 1. Agronomic production and root/shoot ratio dry weight obtained in four maize genotypes with contrasting characteristics for drought tolerance submitted to different water levels in the soil during preflowering.

\begin{tabular}{llccccccr}
\hline & \multicolumn{4}{c}{ Tolerant } & \multicolumn{3}{c}{ Sensitive } \\
\hline Parameter & \multicolumn{2}{c}{ FC } & WD & FC & WD & FC & WD & FC \\
\hline EL & $15.06 \mathrm{Aa}$ & $15.93 \mathrm{Aa}$ & $13.06 \mathrm{Ab}$ & $13.28 \mathrm{Ab}$ & $12.87 \mathrm{Ab}$ & $10.43 \mathrm{Bc}$ & $12.56 \mathrm{Ab}$ & $7.25 \mathrm{Bd}$ \\
$\mathrm{ED}$ & $42.16 \mathrm{Ab}$ & $36.88 \mathrm{Bb}$ & $44.75 \mathrm{Aa}$ & $41.96 \mathrm{Ba}$ & $45.50 \mathrm{Aa}$ & $36.47 \mathrm{Bb}$ & $39.73 \mathrm{Ab}$ & $21.83 \mathrm{Bc}$ \\
NRE & $14.00 \mathrm{Ab}$ & $14.00 \mathrm{Aa}$ & $14.00 \mathrm{Ab}$ & $14.00 \mathrm{Aa}$ & $18.00 \mathrm{Aa}$ & $14.00 \mathrm{Ba}$ & $12.00 \mathrm{Ac}$ & $10.00 \mathrm{Bb}$ \\
GNPR & $28.00 \mathrm{Aa}$ & $21.00 \mathrm{Ba}$ & $25.00 \mathrm{Aa}$ & $22.00 \mathrm{Ba}$ & $26.00 \mathrm{Aa}$ & $18.00 \mathrm{Bb}$ & $23.00 \mathrm{Aa}$ & $10.00 \mathrm{Bc}$ \\
GDW & $138.85 \mathrm{Aa}$ & $111.78 \mathrm{Aa}$ & $137.61 \mathrm{Ab}$ & $136.91 \mathrm{Aa}$ & $172.51 \mathrm{Aa}$ & $80.64 \mathrm{Bb}$ & $111.11 \mathrm{Ab}$ & $57.99 \mathrm{Bb}$ \\
R/S DW & $0.32 \mathrm{Bc}$ & $0.47 \mathrm{Ab}$ & $0.51 \mathrm{Bb}$ & $0.61 \mathrm{Aa}$ & $0.59 \mathrm{Aa}$ & $0.51 \mathrm{Ab}$ & $0.45 \mathrm{Ab}$ & $0.32 \mathrm{Bc}$ \\
HI & $0.55 \mathrm{Aa}$ & $0.51 \mathrm{Aa}$ & $0.55 \mathrm{Aa}$ & $0.51 \mathrm{Aa}$ & $0.58 \mathrm{Aa}$ & $0.43 \mathrm{Bb}$ & $0.46 \mathrm{Ab}$ & $0.32 \mathrm{Bc}$ \\
\hline
\end{tabular}

EL: ear length $(\mathrm{cm})$; ED: ear diameter $(\mathrm{mm})$; NRE: number of rows per ear; NGR: number of grains per row; GDW: grains dry weight (g); R/S DW: root/shoot dry weight; HI: harvest index.

Means followed by the same letter do not differ statistically. Lowercase letters denote comparisons between genotypes within the same soil water level and uppercase letters indicate comparisons between soil water levels within the same genotype. The Scott-Knott test at $5 \%$ probability was applied.

different water condition. On the other hand, droughtsensitive genotypes showed smaller number of rows per ear under water deficit. Under drought conditions, BRS1010 presented the greatest reduction in NRE, which confirms the sensitivity of this genotype to drought.

There was a reduction in the number of grains per row in all genotypes subjected to water deficit in relation to those at field capacity (Table 1). This difference was of $25 \%$ and $22 \%$ for drought-tolerant DKB390 and P30F35, respectively. For the droughtsensitives 2B710 and BRS1010 these differences were $35.7 \%$ and $56.5 \%$, respectively. Therefore, sensitive genotypes showed greater reductions when compared to tolerant genotypes. BRS1010 showed the lowest number of grains per row among the genotypes under drought conditions. It is important to note that this reduction in number of grains per row in sensitive genotypes is an important variable to be observed, since under field capacity this difference was not verified.

Drought caused reductions in ear diameter and number of grain per ear in all genotypes (Table 1). Nevertheless, total grain yield in tolerant genotypes was unaffected by drought. In contrast, the sensitive genotypes 2B710 and BRS1010 presented grain yield decrease of $53.25 \%$ and $47.8 \%$, respectively, when compared to plants at field capacity. Under drought conditions, the tolerant genotypes DKB390 and $\mathrm{P} 30 \mathrm{~F} 35$ showed $42 \%$ more grain yield than the sensitive genotypes, 2B710 and BRS1010.

Under water deficit, a reduction in the total dry weight was observed only for the sensitive genotypes (Table 1). In both water conditions P30F35 showed higher total dry weight than other genotypes. However, it was observed that tolerant genotypes showed an increase in root/shoot ratio dry weight when submitted to water deficit. On the other hand, in 
2B710 this ratio was unaffected and in BRS1010 was reduced. This indicates that under drought conditions the tolerant genotypes invest in root system as a strategy to tolerate water deficit.

It is important to emphasize that the balance in carbon investment between shoot, root and reproductive organs, has a great importance for the final production. Under stress conditions, a percentage of carbon assimilated by plants is partitioned to important mechanisms and structures for drought tolerance. This partitioning can impair grain yield if plant does not have a good partitioning efficiency. This partitioning efficiency can be measured by harvest index, which is important to verify how much carbon the maize plant invests in grain. Thus, harvest index was analyzed in both genotypes under different water conditions and it was observed that droughttolerant genotypes did not change the harvest index when submitted to water deficit (Table 1). Droughttolerant showed higher harvest index than sensitive genotypes. Under drought condition, it was observed a reduction in harvest index of $26.6 \%$ for $2 \mathrm{~B} 710$ and $29.6 \%$ in BRS1010, compared to plants at field capacity.

\section{Discussion}

Drought-tolerant genotypes, DKB390 and P30F35, showed better water adjustment and grain yield in relation to sensitive genotypes, 2B710 and BRS1010, when submitted to water deficit in preflowering. This may be related to the ability of these genotypes to maintain water absorption and carbon partition to support the development of reproductive organs. Thus, it is believed that carbon investment for root growth demonstrated by the higher root/shoot dry weight ratio, during water deficit conditions, allowed tolerant genotypes greater capacity to absorb water (Lynch et al., 2014).

In addition, lower carbon investment for vegetative growth of shoots is an important mechanism to reduce transpiration area and to avoid the water loss in conditions of water deficit. Sensitive genotypes did not invest carbon to root as happened in 2B710. BRS1010 partitioned more carbon to shoot than roots. In this way, sensitive genotypes showed greater imbalance between absorption and loss of water, and this may have cooperated for the lower leaf water potential observed. In fact, Souza et al. (2016) working with droughttolerant genotypes of maize observed that plants with a better development of root system exhibit higher values of water potential under drought conditions.

These results are in agreement with Lavinsky et al. (2015b), which verified that during water deficit BRS1055, a tolerant genotype, exhibited as strategy the increase in root area, investing mainly in growth of fine and very fine roots. In addition, Zhan et al. (2015) evaluating roots of maize under conditions of water deficit, found that plants that invested in growth of greater roots showed increased grains yield in relation to those that invest in growth of superficial roots. This suggests that improvement in the root system architecture is an important characteristic for drought tolerance and deserves close attention to genetic improvement programs that aim to increase drought tolerance in maize crop.

With a decrease in leaf water potential, plants has as its first response the reduction of total growth and leaf area. This occurred because water deficit cause a decrease in cell turgor, which is necessary for cell expansion (Lemoine et al., 2013; Lebon et al., 2006). In addition, plant reduces stomatal conductance as an evolutionary mechanism to prevent water loss. However, a reduction in stomatal conductance 
restricts carbon input to mesophyll, and this reduces carbon concentration close to the carboxylation sites of ribulose-1,5-bisphosphate carboxylase/oxygenase, reducing the photosynthetic process (Ghannoum et al., 2003; Xu et al., 2010).

These affirmations are in agreement with the results obtained in this study, since, in general, there was a reduction in stomatal conductance, transpiration and photosynthesis in all genotypes that were submitted to water deficit. Sensitive genotypes showed a reduction in gas exchange parameters when compared to tolerant ones in drought conditions. On the other hand, tolerant genotypes showed greater ability to manage absorption and loss of water, ensuring greater stomatal conductance and consequently improvements in carbon sequestration (Souza et al., 2013; Magalhães et al., 2015). In addition, Lavinsky et al., (2015a), observed that drought-tolerant genotypes show higher mesophyll conductance when compared to sensitive genotypes. This characteristic ensure to tolerant genotypes higher photosynthetic rate in relation to drought-sensitive genotypes. Thus, it is suggested that in addition to higher stomatal conductance, drought-tolerant genotypes, DKB390 and P30F35, conduct carbon by mesophyll more efficiently in relation to sensitive genotypes, 2B710 and BRS1010, and this may have contributed to greater photosynthesis observed in these genotypes.

Photosynthesis is the gateway of energy in plants, so decrease in photosynthetic rate reduces energy load of cells. This impairs processes that require high levels of energy, such as development of reproductive organs (Setter \& Flannigan, 2001). Therefore, reduction in photosynthesis caused by drought during pre-flowering may have contributed to increase in male and female flowering interval. This occurred mainly in BRS1010, which reduced photosynthesis in drought condition and invested much energy in maintaining vegetative growth of shoots, producing smaller amount of energy to sustain the development of reproductive organs.

The increase in male and female flowering interval (MFFI) caused by drought promoted the loss of synchronism between maturation of male and female gamete. This makes fertilization unfeasible, leading to formation of ear with fewer rows of grains and rows with fewer grains (Edmeades et al., 2000; Duvick, 2005). In this context, it is suggested that lower number of rows per ear observed in BRS1010, under drought condition, can be directly related to the increaseinmaleandfemalefloweringintervalobserved.

Under water deficit, the increase in MFFI may have also corroborated the reduction in number of grains per row observed in all genotypes, especially in 2B710 and BRS1010. Drought-sensitive genotypes showed a greater reduction in the number of grains per row than tolerant ones. However, 2B710, a sensitive genotype, showed male female flowering interval similar to that observed in tolerant genotypes under water deficit. Thus, reduction in number of grains should not only be related to the increase in MFFI. This can be due to the reduction in photosynthesis and subsequent low energy levels that cause grain abortion. These results are in agreement with Boyer and Westgate (2004), which observed that limitation of sucrose to grain, due to the low photosynthetic activity, triggered grains abortion in maize plants submitted to low soil water potential.

Lower photosynthetic rate observed in sensitive genotypes, 2B710 and BRS1010, also explains the reduction in ear length. Besides that, source-sink relationship is compromised and source becomes unable to produce enough carbohydrates to sustain sink growth (Lemoine et al., 2013). The source-sink 
relationship also helps to explain the higher production of tolerant genotypes, DKB390 and P30F35, since they showed higher photosynthetic rates and higher harvest index in relation to BRS1010 and 2B710, sensitive genotypes. Harvest index is a parameter widely used to assess partitioning efficiency that evaluate the capacity of plant to allocate carbon to organ with commercial interest, which in the case of maize, is the grain (Durães et al., 2002).

Improvement in partitioning efficiency was directly related to the ability of sink to canalize higher flow of sucrose to sink growth, a process known as sink force. Unloading of sucrose into sink occurs in two ways: simplastic, with energy consumption and when there is high concentration of sucrose in phloem; and/or by sucrose carriers which are energized by $\mathrm{H}^{+}$-ATPase, which prevails in cereals like maize. Sucrose is unloaded into apoplast of sink cells, where sucrose is cleaved by cell wall invertase into glucose and fructose. After cleavage, these hexoses are transported via hexose phosphate carrier to cytosol. In citosol, UDP-glucose is converted and transported to amyloplastand storage as starch. This carbohydrate is the main reserve in maize grains (Rossi et al., 2015).

For this, it was suggested that the highest harvest index observed in tolerant genotypes may be related to a greater activity of cell wall invertase in tolerant genotypes. Under low soil water potential, Hütsch et al. (2015) observed that high activity of cell wall invertase secured the supply of hexoses for grain development. In addition, Li et al. (2013) performed the overexpression of genes that encoding cell wall invertase in Arabidopsis, maize and rice using 35S promoter of cauliflower mosaic virus (CaMV) and observed an increase in dry weight of 100 grains, in number of grains per ear, in starch content. In grain yield this increase was of $145.3 \%$.
Thus, it is possible that tolerant genotypes, DKB390 and P30F35, during water deficit, allocated sucrose from their reserves to grain filling, since these genotypes showed a reduction in photosynthetic rate, but did not change final dry weight of grains. Under low soil water potential, Yang et al. (2001) observed that in rice plants large amounts of carbohydrates were allocated from stem to grains, since photosynthesis was low and insufficient to sustain the grain filling. Magalhães et al. (1998) studying the causes of stem breakage, during ear maturation, also observed this phenomenon. They verified that stem break was related to the high capacity of the cultivar to partition carbon from stem to ear. Thus, plant produced productive ear, but stem did not have structures to support the weight of shoot and broke. These authors also observed that, in unfavorable environmental conditions, this process happened in greater intensity.

\section{Conclusion}

Drought-tolerant genotypes, DKD390 and P30F35, invest in root growth as a drought tolerance strategy, which ensure greater efficiency between absorption and loss of water. Besides, during drought conditions, tolerant genotypes showed higher stomatal conductance and photosynthetic rates than sensitive genotypes, BRS1010 and 2B710. Tolerant genotypes also exhibit greater efficiency in carbon partitioning for grains, since exhibited higher harvest index and final grain yield.

\section{Acknowledgment}

The authors would like to thank Universidade Federal de Lavras (UFLA), Centro Nacional de 
Pesquisa de Milho e Sorgo (EMBRAPA) and Conselho Nacional de Desenvolvimento Científico e Tecnológico (CNPq).

\section{References}

BERGAMASCHI, H.; DALMAGO, G. A.; BERGONCI, J. I.; BIANCHI, C. A. M.; MÜLLER, A. G.; COMIRAN, F.; HECKLER, B. M. M. Distribuição hídrica no período crítico do milho e produção de grãos. Pesquisa Agropecuária Brasileira, Brasília, DF, v. 39, n. 9, p. 831-839, set. 2004.

DOI: $10.1590 / \mathrm{S} 0100-204 \mathrm{X} 2004000900001$.

BOYER, J. S.; WESTGATE, M. E. Grain yields with limited water. Journal of Experimental Botany, Oxford, v. 55, n. 407, p. 2385-2394, 2004.

DOI: $10.1093 / \mathrm{j} \times \mathrm{bb} / \mathrm{erh} 219$.

DURÃES, F. O. M.; MAGALHÃES, P. C.; OLIVEIRA, A. C. Índice de colheita genético e as possibilidades da genética fisiológica para melhoramento do rendimento do milho. Revista Brasileira de Milho e Sorgo, Sete Lagoas, v. 1, n. 1, p. 33-40, 2002.

DOI: $10.18512 / 1980-6477 /$ rbms.v1n1p33-40.

DUVICK, D. N. The contribution of breeding to yield advances in maize (Zea mays L.). Advances in Agronomy, San Diego, v. 86, p. 83-145, 2005.

DOI: $10.1016 / \mathrm{S} 0065-2113(05) 86002-\mathrm{X}$.

EDMEADES, G. O.; BOLAÑOS, J.; ELINGS, A.; RIBAUT, J.-M.; BÄNZIGER, M.; WESTGATE, M. E. The role and regulation of the anthesis-silking interval in maize. In: WESTGATE, M.; BOOTE, K. (Ed.). Physiology and modeling kernel set in maize. Madison: Crop Science Society of America and American Society of Agronomy, 2000. p. 43-73.

DOI: $10.2135 /$ cssaspecpub29.c4.

FAO. FAOSTAT. Roma, 2015. Disponível em: <http:// faostat3. fao.org/home>. Acesso em: 23 maio 2016.
GHANNOUM, O.; CONROY, J. P.; DRISCOLL, S. P.; PAUL, M. J.; FOYER, C. H.; LAWLOR, D. W. Nonstomatal limitations are responsible for drought-induced photosynthetic inhibition in four C4 grasses. New Phytologist, Cambridge, v. 159, n. 3, p. 599-608, 2003.

DOI: $10.1046 / \mathrm{j} .1469-8137.2003 .00835 . \mathrm{x}$.

HÜTSCH, B. W.; JUNG, S.; SCHUBERT, S. Comparison of salt and drought-stress effects on maize growth and yield formation with regard to acid invertase activity in the kernels. Journal of Agronomy and Crop Science, v. 201, n. 5, p. 353-367, 2015.

DOI: $10.1111 / \mathrm{jac} .12111$.

LAVINSKY, A. O.; MAGALHÃES, P. C.; DINIZ, M. M.; GOMES JR., C. C.; CASTRO, E. M.; ÁVILA, R. G. Root system traits and its relationship with photosynthesis and productivity in four maize genotypes under drought. Cereal Research Communications, Szeged, v. 44, n. 1, p. 1-9, 2015a. DOI: 10.1556/0806.43.2015.029.

LAVINSKY, A. O.; MAGALHÃES, P. C.; ÁVILA, R.; GOMES JR., C. C.; CARNEIRO, N. P. Analysis of maize photosynthesis parameters and whole plant oxidative damage under long-term drought. Advances in Crop Science and Technology, v. 2015b, p. 1-6, 2015b.

DOI: $10.4172 / 2329-8863.1000$ S1-007.

LEBON, E.; PELlEGRINO, A.; LOUARN, G.; LECOEUR, J. Branch development controls leaf area dynamics in grapevine (Vitisvinifera) growing in drying soil. Annals of Botany, London, v. 98, n. 1, p. 175-185, 2006. DOI: $10.1093 / \mathrm{aob} / \mathrm{mcl} 085$.

LEE, R. The outlook for population growth. Science, Washington, v. 333, n. 6042, p. 569-573, 2011.

DOI: $10.1126 /$ science. 1208859 .

LEMOINE, R.; LA CAMERA, S.; ATANASSOVA, R.; DÉDALDÉCHAMP, F.; ALLARIO, T.; POURTAU, N.; FAUCHER, M. Source-to-sink transport of sugar and regulation by environmental factors. Frontiers in Plant Science, v. 4, p. 1-21, 2013.

DOI: $10.3389 /$ fpls.2013.00272. 
LI, B.; LIU, H.; ZHANG, Y.; KANG, T.; ZHANG, L.; TONG, J.; ZHANG, H. Constitutive expression of cell wall invertase genes increases grain yield and starch content in maize. Plant Biotechnology Journal, Oxford, v. 11, n. 9, p. 1080-1091, 2013.

DOI: $10.1111 /$ pbi.12102.

LOBELL, D. B.; GOURDJI, S. M. The influence of climate change on global crop productivity. Plant Physiology, Bethesda, v. 160, n. 4, p. 1686-1697, 2012.

DOI: $10.1104 /$ pp.112.208298.

LYNCH, J. P.; CHIMUNGU, J. G.; BROWN, K. M. Root anatomical phenes associated with water acquisition from drying soil: targets for crop improvement. Journal of Experimental Botany, Oxford, v. 65, n. 21, p. 6155-6166, 2014. DOI: $10.1093 /$ jxb/eru162.

MAGALHÃES, P. C.; LAVINSKY, A. O.; MELO, H. F.; AlveS, J. C.; SOUZA, T. C. de; BARBOSA, A. P.; RIBEIRO, C. Relationship between nitric oxide, enzymatic antioxidant system and ABA in maize under long-term drought. Revista Brasileira de Milho e Sorgo, Sete Lagoas, v. 14, n. 2, p. 155-166, 2015.

DOI: $10.18512 / 1980-6477 /$ rbms.v14n2p155-166.

MAGAlHÃES, P. C.; DURÃES, F. O. M. Fisiologia da produção. In: CRUZ, J. C.; KARAM, D.; MONTEIRO, M. A. R.; MAGAlHÃES, P. C. (Ed.). A cultura do milho. Sete Lagoas: Embrapa Milho e Sorgo, 2008. p. 63-87.

MAGALHÃES, P. C.; DURÃES, F. O. M.; OLIVEIRA, A. C. de. Efeitos do quebramento do colmo no rendimento de grãos de milho. Ciência e Agrotecnologia, Lavras, v. 22, n. 3, p. 279-289, 1998.

ROSSI, M.; BERMUDEZ, L.; CARRARI, F. Crop yield: challenges from a metabolic perspective. Current Opinion in Plant Biology, v. 25, p. 79-89, 2015.

DOI: $10.1016 /$ j.pbi.2015.05.004.
SETTER, T. L.; FLANNIGAN, B. A. Water deficit inhibits cell division and expression of transcripts involved in cell proliferation and endoreduplication in maize endosperm. Journal of Experimental Botany, Oxford, v. 52, n. 360, 1401-1408, 2001

SOUZA, T. C. de; MAGALHÃES, P. C.; CASTRO, E. M. de; ALBUQUERQUE, P. E. P. de; MARABESI, M. A. The influence of ABA on water relation, photosynthesis parameters, and chlorophyll fluorescence under drought conditions in two maize hybrids with contrasting drought resistance. Acta Physiologiae Plantarum, v. 35, n. 2, p. 515-527, 2013.

SOUZA, T. C. de; MAGAlHÃES, P. C.; CASTRO, E. M. D.; DUARTE, V. P.; LAVINSKY, A. O. Corn root morphoanatomy at different development stages and yield under water stress. Pesquisa Agropecuária Brasileira, Brasília, DF, v. 51, n. 4, p. 330-339, 2016.

DOI: $10.1590 / \mathrm{S} 0100-204 \mathrm{X} 2016000400005$.

XU, Z.; ZHOU, G.; SHIMIZU, H. Plant responses to drought and rewatering. Plant Signaling \& Behavior, v. 5, n. 6, p. 649-654, 2010.

DOI: $10.4161 /$ psb.5.6.11398.

YANG, J.; ZHANG, J.; WANG, Z.; ZHU, Q.; WANG, W. Remobilization of carbon reserves in response to water deficit during grain filling of rice. Field Crops Research, Amsterdam, v. 71, n. 1, p. 47-55, 2001. DOI: $10.1016 / \mathrm{S} 0378-4290(01) 00147-2$.

ZHAN, A.; SCHNEIDER, H.; LYNCH, J. Reduced lateral root branching density improves drought tolerance in maize. Plant Physiology, Bethesda, v. 168, n. 4, p. 16031615, 2015. DOI: 10.1104/pp.15.00187. 